\title{
A ATIPICIDADE DAS MEDIDAS EXECUTIVAS NO CÓDIGO DE PROCESSO CIVIL E O EQUILÍBRIO COM OS DIREITOS FUNDAMENTAIS ${ }^{1}$
}

THE ATYPICITY OF EXECUTIVE MEASURES IN THE CIVIL PROCEDURE CODE AND THE BALANCE WITH FUNDAMENTAL RIGHTS

Gabriele Caldas NERY²

ISSUE DOI: 10.21207/2675-0104.2019.927

\begin{abstract}
RESUMO
Pretende-se com o presente artigo, abordar as questões acerca da nova execução implantada no código de processo civil, a execução atípica, verificando a sua aplicabilidade no caso concreto. Devido a tentativas falhas de execução em seu procedimento típico, ou seja, tradicional, o legislador exarou ao dispositivo processual o inciso IV, do artigo 139, em que concede ao juiz determinar todas as medidas necessárias para assegurar o cumprimento de ordem judicial, inclusive nas ações que tenham por objeto prestação pecuniária. Esse novo preceito surgiu com a pretensão de dar maior celeridade e efetividade ao cumprimento de sentença, principalmente ao de pagar coisa certa. O óbice ocorre por ser um artigo genérico, podendo ocorrer à flexibilização de direitos fundamentais do devedor, assim faz-se necessária a análise jurídica desse novo procedimento através de princípios como o da proporcionalidade e de requisitos que devem ser seguidos pelo intérprete para a aplicabilidade de medidas atípicas com mais precisão, a fim de ponderar os direitos e proporcionar um melhor equilíbrio dos mesmos entre os sujeitos da relação processual.
\end{abstract}

Palavras-chave: Execução atípica. Juiz. Proporcionalidade.

ABSTRACT

\footnotetext{
${ }^{1} \mathrm{O}$ presente artigo sintetiza a monografia de conclusão da pesquisa, realizada para o Programa Interno de Bolsas de Iniciação Científica (PIBIC 2018-2019) da Faculdade de Direito de Franca (FDF), Franca/SP.

${ }^{2}$ Discente da Faculdade de Direito de Franca (FDF), Franca/SP. Bolsista do Programa Interno de Bolsas de Iniciação Científica (PIBIC 2018-2019).
} 
The aim of this article is to address the questions about the new execution implemented in the code of civil procedure, the atypical execution, verifying its applicability in the specific case. Due to failed attempts to execute in its typical, that is, traditional procedure, the legislator implemented the procedural provision in Article 139, item IV, which allows the judge to determine all the measures necessary to ensure compliance with a court order, including in action that have the objective of cash benefit. This new precept emerged with the intention of giving greater speed and effectiveness to the fulfillment of the sentence, especially to pay the right thing. The obstacle occurs because it is a generic article, and the debtor's fundamental rights may be relaxed, so it is necessary to legally analyze this new procedure through principles such as proportionality and the requirements that must be followed by the interpreter for the applicability of the debtor. atypical measures more precisely in order to weigh the rights and provide a better balance of them between the subjects of the procedural relationship.

Keywords: Atypical execution. Judge. Proportionality.

\section{INTRODUÇÃO}

A execução que tem por objeto o estudo do presente artigo é o cumprimento de sentença por quantia certa, que corresponde a uma fase complementar do processo de conhecimento. No Brasil, mais da metade das execuções são frustradas, tendo em vista a inadimplência de devedores ao descumprimento de uma obrigação assumida.

Com o intuito de conceder maior celeridade ao processo, diminuir as execuções frustradas e garantir maior efetividade aos direitos do credor, o legislador entabulou ao código de processo civil de 2015, o artigo 139, inciso IV, no qual defere ao juiz amplos poderes para determinar qualquer medida que achar necessária que assegure o cumprimento de ordem judicial.

Essas medidas são nomeadas como atípicas, por serem medidas não tradicionais e não taxadas em lei, do qual o magistrado, através de sua livre apreciação, pode aplicar qualquer medida que achar necessária para o adimplemento da obrigação, até mesmo aquelas que invadem os direitos pessoais do devedor.

Hodiernamente, essas medidas atípicas resultaram aos devedores apreensão de $\mathrm{CNH}$, de passaporte, bloqueio de cartões de crédito, proibição de frequentar certos lugares e de fazer empréstimos. Portanto, a atipicidade das medidas executivas já é realidade no Brasil, e o principal objetivo do presente artigo é analisar os limites da aplicabilidade dessas medidas atípicas no caso concreto, pois as mesmas ao invadir os direitos pessoais, podem invadem direitos fundamentais do devedor.

Para alcançar o desiderato proposto, serão observados os princípios da proporcionalidade, da efetividade e da menor onerosidade para que, assim, no caso de colisão entre direitos fundamentais do 
executado e do exequente, seja realizada uma ponderação entre esses direitos, e por conseguinte, se alcançar um equilíbrio em uma justa medida.

Pretende-se chegar à compreensão da vasta importância dos direitos fundamentais humanos, mas também demonstrar que em caso de conflitos, algum deles podem ser flexibilizados.

\section{A EXECUÇÃO CONTEXTUALIZADA NA EVOLUÇÃO DO DIREITO}

\subsection{A EXECUÇÃO NOS PRIMÓRDIOS DO DIREITO}

As execuções, por um longo período, comportaram-se de forma desumana. Na idade antiga, no direito romano, não existia execução patrimonial, a execução era desferida contra o devedor de forma pessoal, ou seja, na própria pessoa do devedor. Portanto, o patrimônio do executado não era tocado quando existiam inadimplementos de obrigações.

Os métodos pessoais de execução resultavam em castigos como a escravidão, o esquartejamento, e poderia levar até a morte do devedor. Esses brutos métodos de tentativa de pagamento contra o devedor aconteciam quando fosse reconhecido o crédito do credor em uma sentença, ou em uma confissão por meio da Lei das XII Tábuas. Consequentemente, se o devedor não pagasse seu débito, o credor se valeria da força física.

Caso o devedor não pagasse o que era devido ao credor, ele poderia ser vendido como escravo. A lei das XII Tábuas, em sua Tábula Terceira (dos direitos de crédito) proferia sobre o assunto:

Aquele que confessa dívida perante o magistrado ou é condenado, terá 30 dias para pagar. Esgotados os 30 dias e não tendo pago, que seja agarrado e levado a presença do magistrado. Se não paga e ninguém se apresenta como fiador, que o devedor seja levado pelo seu credor e amarrado pelo pescoço e pés com cadeias com peso até ao máximo de 15 libras; ou menos, se assim o quiser o credor. $\mathrm{O}$ devedor preso viverá a sua custa, se quiser; se não quiser, o credor que o mantém preso dar-lhe-á por dia uma libra de pão ou mais, a seu critério. Se não há conciliação, que o devedor fique preso por 60 dias, durante os quais será conduzido em três dias de feira ao comitium, onde se proclamará em altas vozes o valor da dívida. Se são muitos os credores, é permitido, depois do terceiro dia de feira, dividir o corpo do devedor em tantos pedaços quantos 
sejam os credores, não importando cortar mais ou menos; se os credores preferirem, poderão vender o devedor a um estrangeiro, além do Tibre. ${ }^{3}$

Observa-se que nesse período não existiam direitos individuais a serem protegidos, pelo contrário, os direitos pessoais e individuais do devedor eram feridos de forma brutal com castigos pessoais, ofendendo à sua honra, sua vida privada, entre outros direitos.

Logo em seguida, com a influência do cristianismo, foram surgindo leis humanitárias, melhorando a situação do devedor e, assim, beneficiando-o na fase executiva. Tendo em vista essa humanização, em 326 antes de cristo, a Lex Poetalia4, aboliu a pena capital e os meios vexatórios como as prisões e as correntes.

Essa Lex Poetelia surgiu com o intuito de mitigar a instabilidade social provocada pelo sistema da justiça feita pelas próprias mãos, ou seja, a autotutela, atenuando o sistema que estava em vigência, proibindo assim, a morte ou acorrentamento. Consequentemente, com a autorização do juramento do devedor de ter bens a responder pela dívida, livrou-se pessoalmente do jugo do credor, e passou a responder através de seus patrimônios e não por meio de seu próprio corpo, sendo o fim da execução corporal.

Com a imposição da execução patrimonial, quando o credor tivesse reconhecido seu crédito mediante sentença ou confissão do devedor, a execução não poderia mais agir diretamente sobre a pessoa do devedor ou sobre seu patrimônio; passou a ter que entrar com uma nova ação de cognição, a actio iudicati5, para que o juiz exercesse a coerção sobre o devedor, tendo em vista que anteriormente o magistrado não tivesse o poder de executar, mas apenas o poder de jurisdição.

$\mathrm{Na}$ actio iudicati havia a figura do pretor, que era um tipo de magistrado associado à carreira política, que se equiparava a um prefeito ou governador, onde se administrava o poder da justiça em Roma, com a principal finalidade administrar a prestação jurisdicional. Entretanto, o pretor ou praetor não julgava as lides, porque a função de julgar era de um particular (iudex), que era responsável por resolver os litígios em Roma.

\footnotetext{
${ }^{3}$ Disponível em: http://www.dhnet.org.br/direitos/anthist/12tab.htm Acesso em: 02/09/2019

${ }^{4}$ Lei da República Romana que aboliu o nexum, ou seja, o acordo pelo qual um devedor dava como garantia de um empréstimo a escravidão de si próprio (ou de um membro da família sobre o qual ele tinha autoridade, como uma criança) em nome do credor em troca da extinção do débito.

${ }^{5}$ Ação de coisa julgada, ou para efeito de execução de sentença ditada numa ação constitutiva. Procedimento de execução autônomo. OTHON SIDOU, José Maria. Dicionário jurídico: Academia Brasileira de Letras Jurídicas.
} 
Dessa forma, visualizou-se que no direito romano não existia uma função jurisdicional que controlasse a execução, mas sim uma figura particular onde possuía poderes restritos a atividades administrativas no direito romano, não possuindo poderes de julgar as lides.

A ação executiva no Direito Germânico era feita de forma inversa: da execução à cognição, portanto a atividade executiva antecedia a atividade cognitiva. $\mathrm{O}$ credor buscava pessoalmente o seu direito, antes de ação judicial, facultando-lhe penhorar os bens do devedor como forma de coação.

Observa-se que não existia uma ampla defesa para o devedor, de forma que era ausente a figura do contraditório, visto que independia a verificação da real existência da dívida, bastando à palavra do credor como efetiva prova dos fatos. Ausentes esses direitos, as medidas tornavam-se injustas para o devedor, pois o contraditório é o mínimo necessário para o alcanço de uma dignidade. As exigências da época acabaram por criar as linhas básicas da execução forçada: um sistema entre a burocrática e redundante actio iudicati dos romanos e o processo violento dos germânicos.6

Com a expansão comercial e a influência germânica foram criados mecanismos de execução direta de obrigações entre particulares, dispensando assim prévia declaração judicial, possuindo eficácia executiva, agindo de forma mais célere que a ação de conhecimento. Com o passar do tempo, o procedimento utilizado entre a execução de título judicial e extrajudicial foi se diferenciando, nos judiciais foi conservada a sumariedade tradicional; já nos títulos extrajudiciais foi criado um litígio especial, com prazos e defesas especiais.

No final da Idade Média e início da Idade Moderna, surgiram os títulos de crédito, que tutelavam uma forma judicial mais efetiva do que o processo de cognição ordinário. Por consequência, ressurgiu a actio iudicati romana, dispensando a sentença do processo de conhecimento, e autorizando uma forma jurisdicional essencialmente executiva.

A execução foi unificada com a influência do Direito Francês, tendo a executio per officium iudicis e a actio iudicati o mesmo instrumento para cumprimento da obrigação, pois o volume de títulos de créditos era maior que o execuções de sentença obtida pelo processo de cognição. Dessa forma, desapareceu a execução por ofício, reinstaurando-se novamente a execução do antigo sistema romano, chegando, consequentemente, à execução, através de duas ações, uma ação cognitiva,

${ }^{6}$ LIMA, Walber Cunha. Revista da FARN, Natal, v.7, n.2, p. 76, jul,/dez. 2008. 
conduzindo até o fim da sentença condenatória; e a ação executiva, sendo posterior à cognitiva, ambas com o objetivo de satisfazer o direito do credor.

\title{
2.2 A EXECUÇÃO NA ATUALIDADE
}

O Código de Processo Civil Brasileiro de 1939 foi um marco na história do Direito Processual Civil, devido ao seu caráter federal. Anteriormente, era um código processual para cada Estado, com a da presença deste dispositivo, o Direito Processual Civil passou a ser unificado. Esse Código adotou o conceito unitário, existindo apenas um processo de execução para qualquer título, tanto para título executivo judicial quanto para extrajudicial.

Com as mudanças no Código de Processo civil, tratando de títulos executivos judiciais se dispensava o ajuizamento de nova ação, enquanto nos títulos executivos extrajudiciais perdurava o processo autônomo de execução se diferenciando dos judiciais.

Moacir Amaral Santos discorre sobre o processo sincrético:

\begin{abstract}
O tema sobre autonomia do processo de execução é, atualmente, apenas ventilável quando esta se baseia em título extrajudicial, uma vez que a execução de sentença, pela nova disciplina legal, consiste em nova fase processual, no denominado processo sincrético, fase processual, no denominado processo sincrético, que abraça a fase cognitiva e a fase executiva. Logo, a autonomia do processo de execução calcado em título extrajudicial ninguém nega, nem poderia negar dada a sua absoluta desvinculação a qualquer processo anterior. ${ }^{7}$ (Grifei)
\end{abstract}

Com o advento da lei 11.232/2005, foi inserida uma nova fase no processo de conhecimento, chamada "fase do cumprimento de sentença", sendo empregada em decisões judiciais (sentenças) que condenam o devedor a pagar quantia certa. A fase do cumprimento de sentença tem a finalidade de executar atividades cognitivas e executivas dentro do mesmo processo, em uma mesma relação jurídica processual, denominado de processo sincrético, sendo desnecessária uma nova citação. Portanto, essa lei foi composta por um sistema bifásico, possuindo duas fases processuais, a de reconhecimento e, por conseguinte, a de cumprimento.

7 SANTOS, Moacir Amaral. Primeiras linhas de direito processual civil. Vol. III. 22 ed. São Paulo: Saraiva, 2008, p. 244. 
Nesse código de 1973, o devedor tinha prazo de quinze dias para cumprir a obrigação de forma voluntária, sob pena de penhora e avaliação de seus bens, possuindo como fundamento o artigo 475-J do CPC/73. Hodiernamente, o código de processo civil que está em vigência no Brasil é o da lei 13.105/2015,e os maiores propósitos da elaboração desse código são a celeridade processual, a efetividade e a eficácia através de dois princípios, o princípio da máxima efetividade da execução, e o princípio da menor onerosidade ao executado previsto no artigo 8058, do CPC de 2015.

Insta salientar que o Código de Processo civil de 2015 trouxe consigo uma nova forma de execução de cumprimento de sentença por quantia certa: A execução atípica exarada no art. 139, inciso IV do CPC, dando total liberdade para o juiz manifestar sua sentença aplicando quais medidas, que em sua visão contribuirá para a efetividade e adimplemento da obrigação pelo devedor, podendo assim ser devida ou excessiva. De tal modo, além da medida típica de execução patrimonial, de forma subsidiária, possuímos a medida atípica de execução assegurada pelo magistrado.

Dessa forma, pela breve abordagem histórica realizada, é possível notar o grande avanço no processo de execução, o que anteriormente os castigos contra o devedor eram desferidos contra sua integridade física, sem preservação de seus direitos, hodiernamente, em regra geral, a execução é desferida contra o patrimônio do devedor, e, de forma subsidiária, são aplicadas medidas atípicas que o magistrado pode conceder como forma de coagir o devedor a cumprir com sua obrigação.

Destarte, a execução se aperfeiçoou conforme as necessidades do credor e os direitos do devedor. Também é importante notar que houve o desengessamento do poder do magistrado, passando de um poder administrativo para jurisdicional.

\section{$3 \quad$ DIREITOS FUNDAMENTAIS}

O modo como são tratados os direitos fundamentais varia em cada Estado democrático, pois o "conteúdo concreto e a significação dos

\footnotetext{
${ }^{8}$ Art.805. Quando por vários meios o exequente puder promover a execução, o juiz mandará que se faça pelo modo menos gravoso para o executado. Parágrafo único. Ao executado que alegar ser a medida executiva mais gravosa incumbe indicar outros meios mais eficazes e menos onerosos, sob pena de manutenção dos atos executivos já determinados.
} 
direitos fundamentais para um Estado dependem de numerosos fatores extrajurídicos, especialmente das peculiaridades, da cultura e da história dos povos." ${ }^{9}$ Dessa forma, os direitos fundamentais possuem uma índole evolutiva, conforme a histórica for se evoluindo, eles também vão se evoluindo gradativamente.

Os direitos fundamentais são direitos que estão inseridos na constituição federal de 1988 , em seu artigo $5^{\circ}$, sendo uma norma suprema do ordenamento jurídico que resguarda os valores mais importantes da existência humana, onde todos os seres humanos são titulares destes direitos.

Uma das infinitas definições para os direitos humanos fundamentais é "o conjunto institucionalizado de direitos e garantias do ser humano que tem por finalidade básica o respeito a sua dignidade, por meio de sua proteção contra o arbítrio do poder estatal e o estabelecimento de condições mínimas de vida e desenvolvimento da personalidade humana ${ }^{10}$."

Na visão de Canotilho a finalidade dos direitos fundamentais:

A função de direitos de defesa dos cidadãos sob uma dupla perpectiva: (1) constituem, num plano jurídico objetivo, normas de competência negativa para os poderes públicos, proibindo fundamentalmente as ingerências destes na esfera jurídica individual; (2) implicam, num plano jurídico subjetctivo, o poder de exercer positivamente direitos fundamentais (liberdade positiva) e de exigir omissões dos poderes públicos, de forma a evitar agressões lesivas por parte dos mesmos(liberdade negativa). ${ }^{11}$

Para Gilmar Mendes, o avanço do direito constitucional tem como resultado a afirmação dos direitos fundamentais como núcleo da proteção da dignidade da pessoa e da visão que a constituição é o local adequado para positivar as normas asseguradoras dessas pretensões. 12

Dessa forma, é fato que os direitos fundamentais são essenciais para o direito e para a vida humana, que visam garantir a dignidade e a liberdade de cada indivíduo, buscando alcançar uma vida justa e igualitária.

Alguns indivíduos conceituam os direitos fundamentais como universais, no entanto generalizar sem preceituar as exceções é um tanto impróprio, porque assim como no direito brasileiro existem direitos

\footnotetext{
${ }^{9}$ Konrad Hesse, Significado de los derechos fundamentales, in Benda e outros, Manual de derecho constitucional, Madrid: Marci Pons, 1996, p. 84-85.

${ }^{10}$ MORAES, Alexandre de. Direitos humanos fundamentais. São Paulo: Ed. Atlas, 2002,p.39.

${ }^{11}$ CANOTILHO, J.j.Gomes. Direito Constitucional. Coimbra. 1996. p. 541

${ }^{12}$ MENDES, Gilmar Ferreira. Curso de direito constitucional. Editora saraiva, $2^{\mathrm{a}}$ edição. 2008,p.231
} 
fundamentais de todos os homens, como o direito a vida, há também aqueles que se referem a apenas alguns indivíduos, não se ligando a toda e qualquer pessoa, como aos trabalhadores. Portanto, alguns dos direitos fundamentais também podem ser garantidos a uma classe específica de pessoas, e não apenas a uma universalidade.

Também é observado conceito sobre direitos fundamentais serem absolutos, de forma que não existissem restrições a eles. No entanto, também é um conceito errôneo, pois em nosso sistema tornou-se pacífico que os direitos fundamentais podem sofrer limitações, isso ocorre quando confrontam outros valores de ordem constitucional, até mesmo outros direitos fundamentais.

Portanto, observa-se que o direito fundamental não é absoluto, e que possui limitações em certos casos específicos. Deve ser frisado que certas limitações de direitos fundamentais não são malefícios, mas sim uma forma de garantia de atender outros direitos considerados importantes frente a sociedade. Sobre as limitações, Alexandre de Moraes enunciou que "os direitos fundamentais não deve ser utilizado como verdadeiro escudo protetivo de prática de atividades ilícitas"13.

Os direitos fundamentais podem acabar entrando em conflito com outros direitos ou bens constitucionalmente protegidos, devido a isso é necessária uma ponderação para a concretização desses direitos. A admissibilidade de restrição de direitos em casos concretos deve ser analisada no contex to sistemático da constituição, em nome da salvaguarda de outros direitos ou bens.

Ocorre a colisão de direitos fundamentais quando o direito fundamental por parte de seu titular colide com o exercício de um direito fundamental por parte de outro titular14, portanto um conflito de direitos. Devido a essa colisão de direitos, algum acaba sendo restringido em relação a outro, por isso é necessária fazer o juízo de ponderação sob entre esses direitos conflitantes.

Portanto, a melhor forma de realizar a ponderação dos direitos é através do caso concreto, não se eliminando os critérios abstratos que servem de complemento para uma melhor resolução do conflito entre direitos.

A ponderação desses direitos em caso de colisão pode ser feita através do princípio da proporcionalidade, que auxiliará para que não ocorram excessos inadequados no momento de restrição de algum desses

\footnotetext{
${ }^{13}$ MORAES, Alexandre de. Direitos humanos fundamentais. São Paulo: Ed. Atlas, 2002. p. 30

${ }^{14}$ CANOTILHO. J.j. Gomes. Direito Constitucional. 1996. Coimbra.p. 643.
} 
direitos em detrimento do outro, para que a aplicabilidade de uma decisão ocorra de forma mais justa possível. O princípio da dignidade humana tem que ser avaliado em todo o processo, pois é o principio máximo do estado democrático, em que ambas partes são dotadas desse preceito.

O princípio da proibição de excessos ou princípio da proporcionalidade em sentido amplo é utilizado de forma que ao ocorrer qualquer limitação de direitos, ele deverá ser orientado com os outros três princípios: o princípio da conformidade ou adequação; o princípio da exigibilidade ou da necessidade; e o princípio da proporcionalidade em sentido estrito.

O princípio da conformidade ou adequação para Canotilho é:

\begin{abstract}
Medida adoptada para a realização de interesse público deve ser apropriada à prossecução do fim ou fins a ele subjacentes. Consequentemente, a exigência de conformidade pressupõe a investigação e a prova de que o acto do poder público é apto para e conforme os gins justificativos da sua adopção. Trata-se, pois, de controlar a relação de adequação medida-fim. ${ }^{15}$
\end{abstract}

Portanto, a medida aplicada no caso concreto deve ser adequada e de conformidade com fim desejado, de forma que essa conformidade deve ser exigida para que não ocorram medidas excessivas e inadequadas desferidas contra algum cidadão protegido pela carta magna.

O princípio da exigibilidade ou da necessidade ocorre quando o indivíduo tem direito a menor desvantagem possível, ou seja, deve ter comprovação que para a obtenção de determinado fim, não era possível obter um meio menos gravoso para o indivíduo. Deve ser analisado se o juiz poderia ter utilizado outro meio igualmente eficaz e que seria menos desvantajoso para os indivíduos em uma lide.

Por fim, o princípio da proporcionalidade em sentido estrito também chamado de princípio da "justa medida", é utilizado quando "nos meios e fim são colocados em equação mediante um juízo de ponderação, com o objetivo de se avaliar se o meio utilizado é ou não proporcionado em relação ao fim. Pesar as desvantagens dos meios em relação às vantagens do fim".

Portanto, para ser feito um juízo sobre a proporcionalidade da medida deve haver uma rigorosa ponderação e do possível equilíbrio entre o significado da intervenção para o atingido e os objetivos perseguidos pelo legislador.

${ }^{15}$ CANOTILHO, J.J Gomes. Constitucional e teoria da constituição .3 ed. Editora: Almedina. 1991. p. 264. 
Observa-se que o princípio da proporcionalidade é utilizado na jurisprudência do Supremo Tribunal Federal para solução de colisão entre direitos fundamentais, portanto, sua utilização se da por meio de uma "lei de ponderação" em decisões. O fundamento do princípio da proporcionalidade encontra-se no âmbito dos direitos fundamentais, logo deve ser apreciada a necessidade e a adequação da decisão para se analisar a proporcionalidade.

Dessa forma, na aplicabilidade das medidas é indispensável à valorização da necessidade e a adequação à consecução dos fins desejados, o meio é necessário quando não for possível outra possibilidade menos restritiva ou menos invasiva aos direitos fundamentais.

É imperioso o magistrado se atentar a não ultrapassar os limites da discricionariedade que lhe for outorgada, e acabar agindo de forma arbitrária ao aplicar um direito em detrimento de outro. Por isso, as decisões exigem máxima fundamentação pelo magistrado, para se alcançar uma proporcionalidade sem excessos substanciais.

Esse princípio da proporcionalidade ou razoabilidade serve como um instrumento de medida, auxiliando no processo de ponderação. Deve ser utilizando visando o meio mais adequado, necessário e proporcional para alcançar um fim.

Em suas explanações, Robert Alexy afirma que o conflito entre princípios deve ser resolvido através de um "sopesamento entre os interesses conflitantes". Dessa maneira, ele ensina sobre o sopesamento:

\begin{abstract}
A lei de sopesamento mostra que ele pode ser dividido em três passos. No primeiro é avaliado o grau de não-satisfação ou afetação de um dos princípios. Depois, em um segundo passo, avalia-se a importância da satisfação do princípio colidente. Por fim, em um terceiro passo, deve ser avaliado se a importância da satisfação do princípio colidente justifica a afetação ou a não-satisfação do outro princípio. ${ }^{16}$
\end{abstract}

Dessa forma, é visto que os princípios possuem restrições, e que a melhor forma de avaliar qual deverá se sobressair é através de um sopesamento feito pela discricionariedade do magistrado ao julgar os processos, e o que deve ser valorizado é a máxima necessidade e adequação no caso concreto.

Além do princípio da proporcionalidade, o princípio da efetividade também contribui para a análise do presente trabalho. A

\footnotetext{
${ }^{16}$ ROBERT, Alexy. . Teoria de los derechos fundamentales Trad. De Ernesto Gárzon Valdés. Madrid: Centro de Estudios Constitucionales, 1997 .p.594.
} 
garantia à tutela jurisdicional efetiva é um direito fundamental expresso no art. $5^{\circ}$ inciso LXXVIII da CF. Este visa, portanto, não apenas o acesso aos tribunais, mas também possibilitar ao cidadão a defesa de seus direitos por meio da ação.

Esse princípio, que também pode ser chamado de princípio da máxima coincidência possível, visa efetividade processual através de uma tutela efetiva, célere e adequada. O jurista Humberto Theodoro Júnior assevera sobre o princípio da duração razoável do processo:

É evidente que sem efetividade, no concernente ao resultado processual cotejado com o direito material ofendido, não se pode pensar em um processo justo. Não sendo rápida a resposta do juízo para a pacificação do litígio, a tutela não se revela efetiva. Ainda que afinal se reconheça e proteja o direito violado, o longo tempo em que o titular, no aguardo do provimento judicial, permaneceu privado de seu bem jurídico, sem razão plausível, somente pode ser visto como uma grande injustiça. ${ }^{17}$

Não obstante o princípio da efetividade do devido processo legal, ele também passou a ser reconhecido no art. $4^{\mathrm{o}}{ }^{18}$ do Novo Código de Processo Civil, sendo um instrumento da tutela dos direitos, garantindo o direito fundamental à tutela executiva, e abrangendo meios executivos capazes de proporcionar pronta e integral satisfação a qualquer direito merecedor de tutela efetiva.

Humberto Theodoro Júnior ainda faz observações sobre o assunto em questão:

O novo CPC, por seu turno, prevê que essa garantia de duração razoável do processo aplica-se ao tempo de obtenção da solução integral do mérito, que compreende não apenas o prazo para pronunciamento da sentença, mas também para a ultimação da atividade satisfativa. É que a condenação sem execução não dispensa à parte a tutela jurisdicional a que tem direito. A função jurisdicional compreende, pois, tanto a certificação do direito da parte, como sua efetiva realização. Tudo isso deve ocorrer dentro de um prazo razoável, segundo as necessidades do caso concreto. 19

\footnotetext{
${ }^{17}$ JÚNIOR, Humberto Theodoro. Curso de direito processual civil. 57. Ed. Ver., atual. E ampl. Rio de Janeiro: Forense: 2016. p 65.

18 Artigo $4^{\circ}$ do novo CPC/2015. As partes tem o direito de obter em prazo razoável a solução integral do mérito, incluída a atividade satisfativa Disponível em: $\langle$ http://www.planalto.gov.br/ccivil_03/_ato2015-2018/2015/lei/113105.htm>. Acesso em 22 de abril de 2019.

${ }^{19}$ JÚNIOR, Humberto Theodoro. Curso de direito processual civil. 57. Ed. Ver., atual. E ampl. Rio de Janeiro: Forense: 2016. p 77.
} 
Portanto, para o processo se concretizar de forma justa, não é devida somente a sentença, mas também que o direito da parte seja satisfeito. Uma sentença judicial favorável sem a efetiva tutela do direito resulta em uma movimentação da máquina judiciária em vão, e para que isso não aconteça o novo CPC trouxe novas medidas coercitivas, que visam dar ênfase ao princípio da efetividade.

O princípio da efetividade nada mais é do que a capacidade que o processo tem de assegurar o objetivo a que se propõe, a efetividade deve ser avaliada como um princípio necessário para o maior adimplemento dos cumprimentos de sentença. Não obstante a efetividade ser tão importante, ela deve ser buscada observando o respeito aos direitos fundamentais humanos, pois as restrições desferidas contra os direitos dos devedores não devem ser ultrapassadas além de sua dignidade.

Portanto, a razoável duração do processo e a celeridade são direitos garantidos pela Constituição Federal e pelo Código de Processo Civil, devendo ser valorizados, a fim de atender o bem comum e resguardar a dignidade da pessoa humana.

Quanto ao princípio da menor onerosidade, conforme o art. 805 do novo CPC, quando estiverem presentes vários mecanismos de adimplemento do direito do credor, a execução deverá ser efetuada de forma menos onerosa para o devedor. A execução não pode e nem deve ser um instrumento processual de vingança privada contra o executado, pois ele não deve sofrer além do necessário para a satisfação da dívida.

Portanto, através da valorização do princípio da menor onerosidade para o devedor, deve ser evitado, ao máximo, o ônus desnecessário ao executado, se os meios para adimplemento da dívida forem excessivos e abusivos. O princípio da menor onerosidade excessiva deve ser respeitado de forma que não sacrifique absolutamente o princípio da efetividade da tutela executiva, pois ambos os princípios são importantes e apresentam conflitos, pois cada um diz respeito a partes contrapostas no processo.

Devem ser evitados sacrifícios para ambas partes no processo de execução, diante de tal fato está presente o parágrafo único do artigo $805^{20}$ do Novo CPC. O

Em valorização ao princípio da menor onerosidade é vedado aplicar medidas executivas que são incapazes de satisfazer o direito do exequente, isso ocorre para evitar a adoção de uma medida insatisfatória

\footnotetext{
${ }^{20}$ Artigo 805. §ú. Ao executado que alegar ser a medida executiva mais gravosa incumbe indicar outros meios mais eficazes e menos onerosos, sob pena de manutenção dos atos executivos já determinados.
} 
que seria apenas para prejudicar o executado e não beneficiar em nada o exequente, tornando-se assim uma "vingança privada" do credor contra o devedor.

O princípio da menor onerosidade deve ser utilizado sempre de forma harmônica com o princípio da efetividade, pois a expectativa é a maior efetividade com o mínimo de onerosidade, para que, assim, dignidade da pessoa humana não seja infringida. No entanto, o princípio da menor onerosidade ao devedor não deve ser utilizado como forma de fuga de obrigações, pois a menor onerosidade não justifica calotes de máfé.

Assim sendo, o intuito do judiciário e do credor é que o devedor satisfaça a execução de forma positiva adimplindo com seu débito. Em caso infrutífero, o novo código de processo civil criou formas de execução que tem o intuito de proteger os credores, que, na maioria das vezes, eram desprotegidos na relação processual. Em contrapartida, o princípio da menor onerosidade ao devedor deve ser sempre valorizado para não ocorrer infração a carta magna e aos direitos constitucionais do indivíduo, porém, este princípio não é significado de carta branca à inadimplência.

\section{A EXECUÇÃO ATÍPICA NO NOVO CPC}

Em regra, as medidas tradicionais patrimoniais devem ser utilizadas para buscar a efetivação do direito do exequente. No entanto, as medidas não tradicionais no direito processual brasileiro estão sendo aplicadas, quando as medidas típicas se mostram insuficientes para a resolução do problema. $\mathrm{O}$ termo atipicidade se justifica por serem meios executivos não previstos na legislação, porém permitidos.

Esse aparato legislativo do novo Código de Processo Civil veio com a convicção do legislador de causar maior celeridade e efetividade processual, tendo em vista que $75 \%$ (setenta e cinco por cento) das execuções civis no Brasil são frustradas, resultando em inadimplemento das obrigações pactuadas. Estes meios executivos empregam formas coercitivas atípicas que se resumem em invadir os direitos pessoais dos devedores inadimplentes visando à efetivação dos direitos dos devedores exequentes, que mesmo possuindo o título executivo judicial ou 
extrajudicial pode resultar frustrada a execução, devido a atos de má-fé dos devedores para se desviarem da execução judicial. ${ }^{21}$

A medida em apreço é nomeada de subsidiária, pois a mesma só deverá ter aplicabilidade quando todos os outros meios executivos coercitivos típicos estiverem sidos esgotados como tentativa de adimplemento e quitação da dívida. Dessa forma, é inconteste que o juiz deve usar sua liberdade de forma responsável, considerando, a princípio, as formas tradicionais de execução para, posteriormente, aderir à novidade executiva.

As medidas atípicas no Código de Processo civil surgiram com o intuito de viabilizar e satisfazer a obrigação exequenda, sendo forma de efetivação de direitos. No que diz respeito às prestações de fazer ou de não fazer, essas medidas já eram observadas no código antigo, o que não era previsto é a obrigação de pagar quantia certa.

O intuito de manejas as medidas atípicas na execução é o alcance da razoável duração do processo, que é um direito fundamental no qual deve ser protegido, principalmente em processos de cumprimento de sentença que duram anos ou são intermináveis, resultando em suspensão do processo, não possuindo uma duração razoável pelo fato do devedor eventualmente ocultar seus bens patrimoniais.

As medidas atípicas tem como principal artigo de lei o 139, inciso $\mathrm{IV}^{22}$, que representa uma ampliação dos poderes do juiz, permitindo a concessão de medidas destinadas a assegurar a efetivação da tutela pretendida (preventiva ou repressiva), assim como das decisões judiciais. ${ }^{23} \mathrm{~A}$ atipicidade executiva não deve significar ausência de parâmetros, e decisão fundamentada que a determina é imprescindível. ${ }^{24}$ Essa atipicidade deve se impor sempre que não houver procedimento típico ou, em havendo, ele não se mostre eficaz.

O tema despertou muita polêmica no Brasil, apresentando visões doutrinárias diferentes para cada caso. Fernando da Fonseca

\footnotetext{
${ }^{21}$ NERY, Gabriele Caldas. A execução atípica contra a sociedade empresária e a garantia de direitos fundamentais. Franca, 2019. p.56.

${ }^{22}$ Art. 139. O juiz dirigirá o processo conforme as disposições deste Código, incumbindo-lhe: IV determinar todas as medidas indutivas, coercitivas, mandamentais ou sub-rogatórias necessárias para assegurar o cumprimento de ordem judicial, inclusive nas ações que tenham por objeto prestação pecuniária

${ }^{23}$ DONIZETE, Elpídio. Curso didático de direito processual civil. 21. Ed. Ver., atual. E ampl. São Paulo: Atlas, 2018. p. 328

${ }^{24}$ MINAMI, Marcos Yougi. Proposta de concretização dogmática das cláusulas gerais executivas do código de processo civil brasileiro de 2015. p. 85
} 
Gajardoni elucida em seu trabalho que o art. 149, IV revela um real dever de efetivação, sendo que:

(...) diante do risco de violação do correlato dever de efetivação, o juiz, sendo possível, deverá advertir a parte ou o terceiro de que seu comportamento poderá ser considerado ato atentatório à dignidade da justiça; Após, sendo constatada a violação, deverá o juiz: (a) aplicar sanções criminais e civis ao litigante improbe; (ii) aplicar ao responsável multa de até vinte por cento do valor da causa, de acordo com a gravidade da conduta; e(c) tomar as medidas indutivas, coercitivas, mandamentais ou sub-rogatórias necessárias para assegurar o cumprimento da ordem judicial, inclusive nas ações que tenha por objeto prestação pecuniária(astreintes, bloqueio de bens móveis, imóveis, de direitos e de ativos financeiros, restrição de direitos, prolação de decisões substitutivas da declaração de vontade, etc). ${ }^{25}$

Observa-se, portanto, que essas medidas que vieram para flexibilizar os antigos procedimentos de execução, devem ter sua aplicação de forma subsidiária às medidas típicas, e levando em consideração a fundamentação do magistrado quando aplicados.

A doutrina e a jurisprudência possuem um papel essencial na definição de limites para a aplicabilidade do art. 139, IV do CPC, por isso é importante o magistrado analisar com riqueza de detalhes cada caso concreto, visto que as medidas atípicas devem ser utilizadas contra aqueles devedores que frustram a execução com má fé, ocultando seus bens para não adimplir com a obrigação assumida.

O papel do magistrado se reforça com esse dispositivo, e para garantir essa efetividade é de máxima importância que seja observado tanto à satisfação dos direitos fundamentais do credor, quanto à observância dos direitos fundamentais do devedor, para que assim, seja garantido uma justa medida para ambas partes. Para se alcançar essa justa medida devem ser observados os princípios e as garantias constitucionais, como o princípio da proporcionalidade e o da razoabilidade.

O legislador foi extremamente limitado ao inserir esse inciso no código de processo civil, devido a falta de detalhes em que o magistrado deve se guiar, portanto, o legislador não preveu todos os desdobramentos e circunstâncias fáticas de determinado processo judicial. Desta forma, o dispositivo, que positiva genericamente o dever de efetivação, deve ser

\footnotetext{
${ }^{25}$ GAJARDONI, Fernando da Fonseca. O modelo presidencial cooperativista e os poderes e deveres do juiz do novo CPC. In: O novo Código de Processo Civil. Questões controvertidas. Vários autores. São Paulo: Atlas, 2015. p. 142.
} 
utilizado com responsabilidade e cautela, para que a Constituição Federal não seja infringida.

O devedor não pode ser vedado de seus direitos e garantias individuais na aplicabilidade das medidas atípicas, no entanto, o credor também possui seus direitos, nos quais, igualmente, não deve ter seus direitos restringidos em detrimento do devedor. Devido a essa valorização da Constituição Federal e garantias dos direitos fundamentais e da dignidade humana, há uma necessidade do juiz em analisar profunda e minuciosamente o caso concreto na aplicação de medidas atípicas executivas.

$\mathrm{O}$ art. $8^{\circ}{ }^{26}$ do CPC contribuiu para que o magistrado não seja injusto ao aplicar medidas atípicas. Dessa maneira, o ínclito jurista Daniel Amorim em seu trabalho acrescentou que "Trata-se uma extrema relevância jurídica sob a ótica da eficácia da tutela executiva, considerando-se estar o princípio da eficácia da tutela jurisdicional devidamente consagrado no art. $8^{\circ}$ do novo CPC. Pois, justiça ineficiente é sinônimo de ausência de justiça."27

Portanto, ao se deparar em uma situação de aplicabilidade de medida coercitiva atípica, o magistrado deve se valor do art. $8^{\circ}$ do CPC, observando sempre a proporcionalidade da coerção, juntamente com a razoabilidade, a legalidade, a publicidade e a eficiência. Uma medida que não é razoável, ineficiente, ou até mesmo ilegal, não é digna de aplicabilidade, pois resultaria em injusta medida e ineficiência do sistema judiciário. No mais, além desses dispositivos, o $§ 2^{\circ}$ do art.489 $\mathrm{CPC}^{28}$, também deve ser utilizado pelo magistrado, em consonância com o inciso IV, art. 139, em caso de colisão de direitos ou garantias individuais, sob a ótica constitucional, fundamentando exaustivamente suas razões de decisão.

A polêmica dessas medidas começou com a primeira decisão sobre inciso IV, do art. 139, que foi lançada em sede do processo $\mathrm{n}^{\mathbf{o}}$ 4001386-13.2013.8.16.0011, que teve seu tramite no Foro Regional XIPinheiros/SP, em que a juíza vinculada ao processo suspendeu a Carteira

\footnotetext{
${ }^{26}$ Artigo $8^{\circ} \mathrm{CPC} / 2015$. Ao aplicar o ordenamento jurídico, o juiz atenderá aos fins sociais e às exigências do bem comum, resguardando e promovendo a dignidade da pessoa humana e observando a proporcionalidade, a razoabilidade, a legalidade, a publicidade e a eficiência

${ }^{27}$ NEVES, Daniel Amorim Assumpção. Manual de direito processual civil. Vol. Único. Salvador: Juspodvm, 2018,p.15.

${ }^{28}$ Artigo $489, \S 2^{\circ} \mathrm{CPC} / 2015$. No caso de colisão entre normas, o juiz deve justificar o objeto e os critérios gerais da ponderação efetuada, enunciando as razões que autorizam a interferência na norma afastada e as premissas fáticas que fundamentam a conclusão
} 
Nacional de Habilitação do devedor inadimplente, impôs a apreensão de seu passaporte e o cancelamento dos cartões de crédito até o pagamento da dívida.

Ao analisar o referido processo, conclui-se que houve uma colisão entre direitos, no qual o credor, com seu direito do recebimento de crédito busca que seu direito à efetividade seja garantido. Em contrapartida, o devedor, ao se deparar com uma medida coercitiva atípica como a restrição da $\mathrm{CNH}$, o bloqueio do passaporte e de cartões de crédito, requer o seu direito a menor onerosidade excessiva na execução.

$\mathrm{O}$ direito a efetividade $\mathrm{e} \mathrm{o}$ direito a menor onerosidade à execução são dois princípios que, neste caso concreto, estavam com conflito. O doutrinador Robert Alexy, conforme já foi estudado, elucida que na presença de conflito entre princípios, ele deve ser resolvido por meio de um "sopesamento entre os interesses conflitantes", desse modo, através do sopesamento é analisado o peso de cada princípio, e se utilizando do princípio da proporcionalidade, é possível chegar a uma medida mais justa possível para as partes.

No que tange a suspensão da $\mathrm{CNH}$, ela não impede o direito de ir e vir do devedor, de forma que ele pode se locomover de outros modos além de dirigir, por meio de ônibus de linha, por metrô, através de caronas, de táxi, por aplicativos de carona "uber" "99", por avião, bicicleta, ou até mesmo a pé. Em relação ao pedido de restrição de $\mathrm{CNH}$, deve ser observado se o devedor não a utiliza para o exercício de um serviço, pois restringir o indivíduo a exercer sua atividade laboral é ir contra um direito fundamental humano, mas essa utilização laboral deve ser provada.

$\mathrm{Na}$ caso em apreço a magistrada observou que o réu não possuía bens para quitar a dívida, mas teria feito viagens internacionais. Ora, é mais do que fato que aquele que possui condições financeiras para fazer uma viagem internacional, possui condições para adimplir um débito, portanto, era inconteste que o executado estava frustrando de má-fé sua obrigação. Nesse caso, ao fazer o sopesamento, o direito à efetividade do credor se sobressaiu em detrimento do direito à locomoção do credor.

Além do mais, deve se observar que essas medidas são temporárias e coercitivas, e não punitivas, portanto, restringir o direito ao passaporte do indivíduo é uma forma de coagi-lo a quitar com seu débito antes de fazer uma viagem internacional à lazer.

Em contrapartida a efetividade do adimplemento da obrigação através dessas duas medidas, a decisão sobre o cancelamento dos cartões de crédito até o cumprimento da obrigação é uma medida considerada 
excessiva. Pois, hodiernamente, o cartão de crédito é utilizado em qualquerocasião, e ter cartão de crédito não significa que o devedor terá gastos com lazer, ou com produtos onerosos, pelo contrário, com o cartão o indivíduo se alimenta, cuida de sua higiene pessoal, fazendo compras em mercados; se veste, comprando roupas e utensílios domésticos em lojas; todos esses direitos são direitos fundamentais da pessoa humana expressos no art. $5^{\circ}$, inciso $\mathrm{X}$ da Constituição Federal, no qual garante a não inviolabilidade a intimidade, a vida privada, a honra e a imagem das pessoas, esses direito garantem a dignidade da pessoa humana.

Portanto, ao fazer um sopesamento entre o direito à efetividade do credor e o direito a intimidade e a vida privada do devedor, em uma proporcionalidade, o mais adequado e justo é a valorização dos direitos do devedor, pois o direito a alimentar-se, a vestir-se, e a higienizar-se, devem ter pesos maiores do que à efetividade de uma obrigação. Neste caso, a nobre magistrada se equivocou ao decidir pelo cancelamento do cartão de crédito se atentando contra a dignidade da pessoa humana, que deve ser valorizada acima de tudo.

Para finalizar a análise da jurisprudência em questão, nota-se que, primeiramente, o manejo dessas medidas só foram utilizadas após o esgotamento das medidas tradicionais previstas em lei, além disso, o contraditório foi devidamente utilizado, tendo em vista que o executado foi intimado várias vezes para adimplir a dívida ou justificar o não adimplemento.

Ato contínuo, para a devida garantia de justa medida, o juiz deve sempre fundamentar exaustivamente sua decisão, nos moldes do art. 489 do CPC, fato que foi adequadamente feito pelo magistrado, que justificou e fundamentou todos os motivos que a levaram chegar a tal decisão.

Outros requisitos a serem seguidos para uma prudente aplicabilidade do inciso IV do art. 139 CPC são a razoabilidade e customização, porque as medidas impostas pelo magistrado devem ter capacidade de coagir o devedor. A incapacidade de coagir seria uma medida inadequada, que só movimentaria o judiciário sem um resultado frutífero. No caso em análise, a magistrada se utilizou da razoabilidade, pois ao deparar-se com a notícia que o devedor fazia viagens internacionais, aplicou a suspensão da CNH e a apreensão do passaporte, logo, se o indivíduo se utiliza de passaporte para viagens, a apreensão do passaporte serviria como forma de coagi-lo a satisfazer o débito.

Portanto, estavam presentes provas ou indícios de ocultação patrimonial pelo devedor, e as medidas de suspensão da $\mathrm{CNH}$ e apreensão 
do passaporte foram medidas adequas contra o indivíduo que agiu de máfé, pois o dispositivo em questão deve ser utilizado para os executados que agem de má-fé contra o judiciário, e não contra o devedor que age de boafé e não possui bens para indicar.

As garantias constitucionais devem ser sempre analisadas na aplicação de medidas atípicas, e a magistrada se excedeu ao decidir pelo cancelamento dos cartões de crédito, pois feriu um direito fundamental humano, que deve ser preservado e valorizado. Com o cancelamento do cartão de crédito, a medida se tornaria excessiva e desproporcional, resultando em uma onerosidade excessiva.

\section{CONSIDERAÇÕES FINAIS}

A execução evoluiu historicamente contendo características diferentes de medidas executivas até se chegar ao novo modelo de execução atípica do art. 139, IV do CPC/2015. Esse dispositivo veio para inovar a sistemática processual da busca da efetividade e celeridade, sendo as medidas nomeadas de atípicas por serem não tradicionais de execução.

Essas medidas por atingirem o direito pessoal do devedor são subsidiárias, e sua aplicabilidade depende do esgotamento das vias típicas e tradicionais de execução para que assim não resultem em injustiças na relação processual.

O problema desse artigo é ser um dispositivo genérico, onde atribui ao juiz à aplicabilidade de toda e qualquer medida que ele achar necessária para a satisfação da obrigação. Portanto, o magistrado deve estabelecer limites na aplicabilidade da medida no caso concreto, devendo se orientar através de requisitos estabelecidos pela doutrina, pela jurisprudência e por princípios gerais, processuais e constitucionais do direito para uma tutela eficiente, justa e equilibrada da medida.

Ao analisar esse novo formato de execução é necessário estudar os direitos fundamentais humanos e utilizar-se do princípio da proporcionalidade e da menor onerosidade ao devedor, e assim fazer uma análise minuciosa dos direitos de ambas as partes, onde de um lado deve ser valorizado o princípio da efetividade, que possui o intuito de garantir a efetividade do cumprimento de sentença, o adimplemento da obrigação e assim satisfazer o direito do credor; e de outro lado o princípio da menor onerosidade ao devedor valorizando os direitos do devedor, não permitindo 
medidas que sejam tão extremas que se tornem onerosas e prejudiciais ao devedor ferindo seus direitos fundamentais ou sua dignidade.

Desse modo, quando há colisão de direitos ou princípios, o julgador deve se utilizar de uma ponderação entre direitos através do princípio da proporcionalidade, onde serão dispostos a um sopesamento para se analisar qual direito poderá ser restringido em detrimento de outro, de forma que alcance uma proporcionalidade e justa medida entre os dois direitos, da efetividade e da menor onerosidade.

Por fim, o art. 139, IV do CPC deve ser utilizado sempre resguardando os direitos fundamentais e a dignidade da pessoa humana, se atentando a proporcionalidade, a razoabilidade, a legalidade e a efetividade.

\section{REFERÊNCIAS BIBLIOGRÁFICAS}

ALEXY, Robert. Sobre o conceito da dimensão do peso, cf. Ronald Dworkin, Taking Rights, Seriously.

BARROSO, Luis Roberto. Curso de direito constitucional. Os conceitos fundamentais e a construção do novo modelo. 4 ed. Editora saraiva. 2013.

BOBBIO, Noberto. A era dos direitos, Rio de Janeiro: Campos, 1992.

CANOTILHO, J.J.Gomes. Direito Constitucional. Coimbra. 1996

CANOTILHO, José Joaquim Gomes. Direito constitucional e Teoria da Constituição. 3 ed. Editora Almedina. 1991.

D’ARCE, Marconi. A aplicação dos meios coercitivos do NCPC nos processos de execução à luz do princípio da efetividade. Disponível em:

https://www.migalhas.com.br/dePeso/16,MI253273,31047A+aplicacao+dos+meios+coercitivos+do+NCPC+nos+processos+d e+execucao+a).

DONIZETE, Elpídio. Curso didático de direito processual civil. 21. Ed. Ver., atual. E ampl. São Paulo: Atlas, 2018.

GAJARDONI, Fernando da Fonseca. O modelo presidencial cooperativista e os poderes e deveres do juiz do novo CPC. In: O novo Código de Processo Civil. Questões controvertidas. Vários autores. São Paulo: Atlas, 2015. 
HESSE, Konrad. Significado de los derechos fundamentales, in Benda e outros, Manual de derecho constitucional, Madrid: Marci Pons, 1996.

JÚNIOR, Humberto Theodoro. Curso de direito processual civil. 57. Ed. Ver., atual. E ampl. Rio de Janeiro: Forense: 2016.

LIMA, Walber Cunha. Revista da FARN, Natal, v.7, n.2, jul,/dez. 2008.

MARQUES, José Frederico. Manual de direito processual civil. Vol I. 2 ed. São Paulo: Saraiva, 1998.

MENDES, Gilmar Ferreira. Curso de direito constitucional. Editora saraiva, 2ª edição. 2008.

MINAMI, Marcos Yougi. Proposta de concretização dogmática das cláusulas gerais executivas do código de processo civil brasileiro de 2015.

MORAES, Alexandre de. Direitos humanos fundamentais. São Paulo: Ed. Atlas, 2002.

NERY, Gabriele Caldas. A execução atípica contra a sociedade empresária e a garantia de direitos fundamentais. Franca, 2019.

NEVES, Daniel Amorim Assumpção. Manual de direito processual civil. Vol. Único. Salvador: Juspodvm, 2018.

ROBERT, Alexy. Teoria de los derechos fundamentales Trad. De Ernesto Gárzon Valdés. Madrid: Centro de Estudios Constitucionales, 1997.

RODRIGUES, Clóvis Fredizzi. Exceção de pré-executividade: uma visão constitucional. CD-ROM Juris Síntese Millenium; legislação, jurisprudencial, doutrina e pratica processual. Sintese, São Paulo, n. 40, mar/abr. 2003.

SANTOS, Moacir Amaral. Primeiras linhas de direito processual civil. Vol. III. 22 ed. São Paulo: Saraiva, 2008.

SARLET, Ingo. A eficácia dos direitos fundamentais, Porto Alegre: Livr. Do Advogado Ed.,1998. 